\title{
Pengaruh Motivasi Orang Tua terhadap Minat Baca Siswa Kelas III SD Inpres 26 Kabupaten Sorong Tahun Pelajaran 2016/2017
}

\author{
Mursalim $^{1}{ }^{1}$ Solehun $^{2 \&}$ Rian Pramudia $^{3}$ \\ Program Studi PGSD, Universitas Pendidikan Muhammadiyah Sorong, Indonesia \\ E-mail: mursalim47@gmail.com
}

\begin{abstract}
Abstrak
Penelitian ini bertujuan mengetahui pengaruh motivasi orang tua terhadap minat baca seorang anak dan mengentahui hal apa aja yang menjadi daya tarik siswa agar mempunyai minat untuk membaca yang tinggi. Penelitian ini menggunakan pendekatan eksperimen yang dikaji dengan cara kuantitatif. Populasi penelitisn ini adalah seluruh siswa kelas III berjumlah 31 siswa, sedangkan sampel berjumlah 20 siswa dengan terdiri dari 10 siswa laki-laki dan 10 siswa perempuan yang dipilih secara random. Instrumen yang digunakan adalah angket yang terlebih diuji reliabilitas dan validitas instrumen. Hasil data yang diperoleh diuji menggunakan teknik analisis regresi linier sederhana. Hasil penelitian ini menunjukkan bahwa terdapat pengaruh yang mendorong minat siswa untuk membaca diperoleh hasil $\mathrm{t}$ hitung $=19>\mathrm{t}$ tabel $=1,729$ maka sekitar 75\% siswa memperoleh motivasi yang baik sehingga $80 \%$ memiliki minat baca yang tinggi. Sehingga hasil penelitian ini dapat disimpulkan bahwa motivasi orang tua berperan besar dalam membentuk sebuah minat untuk membaca buku dalam diri seorang siswa yang dimana apabila terus dilakukan akan berdampak sangat baik bagi prestasi maupun masa depan siswa tersebut.
\end{abstract}

Kata Kunci: motivasi orang tua; minat baca.

\begin{abstract}
The purpose of this study is to know the effect a parent's motivation has on a child's interest in reading and to discern what interest the student has in having a keen interest in reading. The study employed an experimental approach discussed in a quantitative way. This research population is a total of 31 students, while the sample number is 20 students with a random selection of 10 male students and 10 female students. The instruments used are the pellets which are more reliably tested and the validity of the instruments. The data results obtained are tested using a simple, linear regression analysis technique. This study suggests that the influence that prompted students' interest in reading was obtained from $t$ count $=19>t$ table $=1.729$ and that about $75 \%$ of students get good motivation for $80 \%$ to have a high reading interest. So the result of this study may be concluded that parental motivation is instrumental in shaping an interest in reading a book ina student that, if carried on, would have a profound impact on both the student's achievements and his or her future.
\end{abstract}

Keywords: Motivations of parents; Interest in Reading. 


\section{PENDAHULUAN}

Membaca merupakan suatu kegiatan interaktif untuk memetik serta memahami arti yang terkandung dalam bahan tulis (Somadoyo, 2011:4). Budaya membaca merupakan cerminan kemajuan suatu masyarakat atau bangsa. Hal ini dibenarkan oleh Zuchdi (2012: 17), yang mengatakan bahwa membaca dan menulis merupakan instrumen utama dari tradisi keilmuan yang menjadi pemacu perubahan sebuah bangsa. Masyarakat yang maju akan senantiasa menjadikan kegiatan membaca sebagai kebutuhan hidup yang harus dipenuhi.

Menurut Rahim (2012:1) manfaat membaca diantaranya membuat seseorang memperoleh pengetahuan dan wawasan baru yang yang akan semakin meningkatkan kecerdasannya sehingga mereka lebih mampu menjawab tantangan hidup di masa mendatang. Membaca membuat orang selangkah lebih maju dibandingkan orang lain. Dengan kata lain, keberhasilan hidup seseorang salah satunya bergantung pada aktivitas membacanya.

Hal yang penting diperhatikan dalam kegiatan membaca ialah kemampuan seseorang untuk memahami makna bacaan secara menyeluruh, atau yang disebut dengan kemampuan membaca pemahaman. Menurut Rubin dalam Somadoyo (2011:7) membaca pemahaman adalah proses intelektual yang kompleks yang mencakup dua kemampuan utama, yaitu penguasaan makna kata dan kemampuan berpikir tentang konsep verbal.

$$
\text { Hardjasujana dkk }
$$

menyatakan bahwa membaca pemahaman merupakan salah satu strategi membaca yang bertujuan untuk memberikan penilaian terhadap karya tulis dengan jalan melibatkan diri sebaik-baiknya pada bacaan dan membuat analisis yang dapat dihandalkan. Seseorang dikatakan memahami bacaan secara baik apabila ia mampu untuk menangkap arti kata yang digunakan penulis, mampu menangkap makna yang tersurat dan tersirat, serta dapat membuat kesimpulan. Sejalan dengan pendapat di atas, Turner dalam Somadoyo (2011: 10) mengungkapkan bahwa seorang pembaca dikatakan memahami bahan bacaan secara baik apabila pembaca dapat: 1) mengenal katakata atau kalimat yang ada dalam bacaan dan menegtahui maknanya; 2) menghubungkan makna dari pengalaman yang dimiliki dengan makna yang ada dalam bacaan; 3) memahami seluruh makna secara kontekstual; dan 4) membuat pertimbangan nilai isi bacaan berdasarkan pengalaman membaca.

Salah satu program pemerintah dalam meningkatkan kualitas sumber daya manusia melalui Departemen Pendidikan Nasional adalah dengan meningkatkan kualitas baca tulis di kelas awal dimana dalam pelaksanaanya siswa dituntut untuk memahami serta mengerti kosa kata Bahasa Indonesia yang baik dan benar. Papua dan Papua Barat memiliki total populasi lebih dari 3,9 juta jiwa ( BPS, 2015 ). Menurut Elmslie (2010) pada tahun 2010, 47,89\% dari total populasi merupakan penduduk asli. Sekitar $70 \%$ dari populasi tinggal di daerah pedalaman dan terpencil yang ditandai dengan adanya kesenjangan pendidikan antara kelompok sosial-ekonomi yang berbeda, serta antara penduduk asli dan pendatang.

Berdasarkan observasi yang dilakukan peneliti pada bulan Maret tahun 2015 mengidentifikasi bahwa mayoritas orang tua kurang memberikan motivasi dan dukungan kepada siswa kelas III SD Inpres 26 Kabupaten Sorong untuk belajar di rumah terutama dalam hal membaca, hal itu diperkuat dengan keterangan guru kelas serta kepala sekolah yang membenarkan bahwa motivasi orang tua untuk mendukung anaknya membaca sangatlah kurang karena orang tua hanya 
menyerahkan semua hal yang berkaitan dengan pembelajaran kepada sekolah dan tidak memberikan pelajaran tambahan di rumah. Padahal disisi lain kecendrungan orang tua yang memberikan dukungan motivasi sangat berdampak besar terhadap minat baca siswa, karena akan mendukung perkembangan belajar siswa baik dari segi akademik maupun non akademik. Mayoritas siswa kelas awal yang ditemui kurang bisa membaca dengan baik sehingga menghambat dalam pelaksanaan pelajaran yang lainya dikarenakan tidak mampu mengenali huruf dengan baik. Kendala lain yang dihadapi adanya sikap acuh tak acuh dari orang tua siswa (Mursalim, 2020). Selain itu lokasi sekolah yang berada di daerah pinggiran membuat orang tua juga kurang memberikan dorongan agar anaknya rajin pergi ke sekolah setiap hari.

Disisi lain kuranganya ketersedian buku bacaan untuk siswa baik di rumah maupun di sekolah juga berpengaruh terhadap minat baca siswa karena terbatasnya sumber belajar yang didapatkan oleh siswa serta model mengajar guru yang kurang memperhatikan perkembangan siswa. Hasil penelitian baseline survey oleh Myriad (2015) menunjukan bahwa kemampuan membaca 60\% siswa kelas III SD Inpres 26 Kabupaten Sorong tidak mampu membaca dan hanya $40 \%$ siswa yang mampu membaca dengan pemahaman terbatas. Penelitian yang sama juga menunjukan $20 \%$ siswa tidak pernah belajar membaca dirumah dan hanya $45 \%$ yang belajar membaca seminggu sekali di rumah. Berdasarkan teori dan permasalahan di atas, maka perlu suatu penelitian tentang "Pengaruh Motivasi Orang Tua Terhadap Minat Baca Siswa Kelas III di SD Inpres 26 Kabupaten Sorong Tahun Pelajaran 2016 / 2017”.

Tujuan penelitian ini adalah untuk mengetahui pengaruh motivasi orang tua terhadap minat baca siswa kelas III di SD Inpres 26 Kabupaten Sorong. Penelitian ini memberikan manfaat kepada orang tuan dan guru bahwa membaca merupakan hal penting yang harus diupayakan sehingga sebuah motivasi perlu diberikan kepada anak agar giat membaca.

Dalam Kamus Besar Bahasa Indonesia kontemporer adalah keinginan atau dorongan yang timbul pada diri seseorang baik secara sadar maupun tidak sadar untuk melakukan sesuatu perbuatan dengan tujuan tertentu (Salim, 2012:997). Sutrisno (2011:109), motivasi adalah suatu faktor yang mendorong seseorang untuk melakukan aktivitas tertentu. Selanjutnya menurut Donald dalam Sardiman (2016:73), bahwa motivasi adalah perubahan energi dalam diri seseorang yang ditandai dengan munculnya "feeling" dan didahului dengan tanggapan terhadap adanya tujuan. Dari pengertian yang dikemukakan Donald ini mengandung tiga elemen penting: 1) motivasi itu mengawali terjadinya perubahan energi pada diri setiap individu manusia. Perkembangan motivasi akan membawa beberapa perubahan energi di dalam sistem "neurophysiological" yang ada pada organisme manusia. Karena menyangkut perubahan energi manusia (walaupun motivasi itu muncul dari dalam diri manusia), penampakkannya akan menyangkut kegiatan fisik manusia. 2) motivasi ditandai dengan munculnya rasa/feeling, afeksi seseorang. Dalam hal ini motivasi relevan dengan persoalan-persoalan kejiwaan, afeksi dan emosi yang dapat menentukan tingkah laku manusia. 3) motivasi akan dirangsang karena adanya tujuan. Motivasi dalam hal ini sebenarnya merupakan respon dari suatu aksi, yakni tujuan. Motivasi memang muncul dari dalam diri manusia, tetapi kemunculannya karena terangsang/terdorong oleh adanya unsur lain, dalam hal ini adalah tujuan. 
Menurut Sardiman (2016:85) mengemukakan tiga fungsi motivasi yaitu: 1) mendorong timbulnya tingkah laku atau perbuatan. Tanpa motivasi tidak akan timbul suatu perbuatan. Motivasi dalam hal ini merupakan motor penggerak dari setiap kgiatan yang akan dikerjakan; 2) motivasi berfungsi sebagai pengarah. Artinya motivasi mengarahkan perubahan untuk mencapai yang diinginkan. Dengan demikian, motivasi dapat memberikan arah dan kegiatan yang harus dikerjakan sesuai dengan rumusan tujuannya; 3) motivasi berfungsi sebagai penggerak. Artinya menggerakkan tingkah laku seseorang. Selain itu, motivasi belajar berfungsi sebagai pendorong usaha dan pencapaian prestasi. Rohani dan Ahmadi (2010:10), motivasi pada siswa dapat tumbuh melalui cara mengajar yang bervariasi, mengadakan pengulangan informasi, memberikan stimulus baru, misalnya melalui pertanyaan-pertanyaan kepada peserta didik, memberikan kesempatan kepada peserta didik menyalurkan belajarnya, menggunakan media dan alat bantu yang menarik perhatian peserta didik, seperti gambar, foto, video, dan lain sebagainya.

Motivasi orang tua yang diberikan kepada anak sangatlah penting karena membawa pengaruh yang besar dalam keberhasilan anak tersebut di masa depan. Orang tua tidak hanya memberikan perhatian namun harus memberikan dorongan yang lebih dalam setiap tahap pembelajaran anak. Dalam perkembangannya seorang siswa tidak hanya butuh motivasi dan perhatian orang tua tapi juga dukungan secara nyata baik secara jasmani dan rohani sehingga pola belajarnya dapat menunjukan hasil terutama yang dibutuhkan siswa kelas III. Kecendrungan orang tua hanya membebankan pembinaan mental dan tanggung jawab pendidikan terhadap guru, hal itu terlihat dari fasilitas belajar yang minim di rumah dan kurangan pendampingan belajar di rumah sehingga minat membaca siswa kelas III terkesan sangat kurang.

Minat adalah kecenderungan jiwa yang relatif menetap kepada diri seseorang dan biasanya disertai dengan perasaan senang (Fathurrohman \& Sulistyorini, 2012:173). Selanjutnya menurut Slameto (2010:57) minat adalah kecenderungan yang tetap untuk memperhatikan dan mengenang beberapa kegiatan. Kegiatan yang diminati seseorang, diperhatikan terus menerus yang disertai rasa senang. Hilgrad dalam Slameto (2010:57) menyatakan "Interest ispersisting tendency to pay attention to and enjoy some activity and content." Minat adalah kecenderungan yang tetap untuk memperhatikan dan mengenang beberapa kegiatan. Kegiatan yang diminati diperhatikan terus menerus dengan disertai rasa senang dan diperoleh rasa kepuasan. Lebih lanjut dijelaskan minat adalah suatu rasa suka dan ketertarikan pada suatu hal atau aktivitas tanpa ada yang menyuruh. Minat adalah kecenderungan dalam diri individu untuk tertarik pada suatu objek atau menyenangi suatu objek. Berdasarkan pendapat yang dikemukakan oleh para ahli di atas, disimpulkan bahwa minat adalah perhatian, rasa suka dan rasa ketertarikan seseorang (siswa) terhadap belajar yang ditunjukkan dengan adanya partisipasi, keinginan siswa untuk belajar dengan baik dan perhatian siswa dalam materi pelajaran secara aktif dan serius.

Rahim (2012:28) mengemukakan bahwa minat baca ialah keinginan yang kuat disertai usaha-usaha seseorang untuk membaca. Seseorang yang mempunyai minat membaca yang kuat akan diwujudkannya dalam kesediaannya untuk mendapat bahan bacaan dan kemudian membacanya atas kesadaran sendiri atau dorongan dari luar. Menurut 
Wahadaniah yang dikutip Ratnasari (2011:16) minat baca adalah suatu perhatian yang kuat dan mendalam disertai dengan perasaan senang terhadap kegiatan membaca sehingga dapat mengarahkan seseorang untuk membaca dengan kemauannya sendiri atau dorongan dari luar. Minat membaca juga merupakan perasaan senang seseorang terhadap bacaan karena adanya pemikiran bahwa dengan membaca itu dapat diperoleh kemanfaatan bagi dirinya.

Berdasarkan pendapat di atas, dapat disimpulkan bahwa minat baca terkandung unsur keinginan, perhatian, kesadaran dan rasa senang untuk membaca. Minat baca adalah suatu kecenderungan kepemilikan keinginan atau ketertarikan yang kuat dan disertai usaha-usaha yang terus menerus pada diri seseorang terhadap kegiatan membaca yang dilakukan secara terus menerus dan diikuti dengan rasa senang tanpa paksaan, atas keinginannya sendiri atau dorongan dari luar sehingga seseorang tersebut mengerti atau memahami yang dibacanya.

Dawson dan Bamman (Fitriana, 2012:64) mengemukakan prinsip-prinsip yang mempengaruhi minat baca sebagai berikut : 1) seseorang atau siswa dapat menemukan kebutuhan dasarnya lewat bahan-bahan bacaan jika topik, isi, pokok persoalan, tingkat kesulitan, dan cara penyajiannya sesuai dengan kenyataan individunya. Isi dari bahan bacaan yang menarik dan sesuai dengan kebutuhan individu, merupakan salah satu faktor yang berpengaruh terhadap minat bacanya; 2) kegiatan dan kebiasaan membaca dianggap berhasil atau bermanfaat jika siswa memperoleh kepuasan dan dapat memenuhi kebutuhan-kebutuhan dasarnya, yaitu rasa aman, status, kedudukan tertentu, kepuasan efektif dan kebebasan yang sesuai dengan kenyataan serta tingkat perkembangannya.

Kegiatan membaca dianggap menguntungkan seseorang, maka membaca merupakan suatu kegiatan yang dianggap sebagai salah satu kebutuhan hidupnya; 3) tersedianya sarana buku bacaan dalam keluarga merupakan salah satu faktor pendorong terhadap pilihan bahan bacaan dan minat baca. Ragam bacaan yang memadai dan beraneka ragam dalam keluarga akan sangat membantu anak dalam meningkatkan minat baca; 4) tersedianya sarana perpustakaan sekolah yang relative lengkap dan sempurna serta kemudahan proses peminjamannya merupakan faktor besar yang mendorong minat baca siswa; 5) adanya program khusus kurikuler yang memberikan kesempatan siswa untuk membaca secara periodik di perpustakaan sekolah sangat mendorong perkembangan dan peningkatan minat baca siswa; 6) saran-saran teman sekelas sebagai faktor eksternal dapat mendorong timbulnya minat baca siswa. Pergaulan teman dalam sekolah menjadi salah satu faktor penting dalam pembentukan minat. Siswa yang berminat terhadap kegiatan membaca, akan lebih sering mengajak temannya ikut melakukan kegiatan membaca baik di dalam kelas ataupun perpustakaan sehingga memberikan pengaruh positif juga terhadap temannya; 7) faktor guru yang berupa kemampuan mengelola kegiatan dan interaksi belajar mengajar, khususnya dalam program pengajaran membaca. Guru yang baik harus mengetahui karakteristik dan minat anak. Guru bisa menyajikan bahan bacaan yang menarik dan bervariasi supaya siswa tidak merasa bosan; 8) faktor jenis kelamin juga berfungsi sebagai pendorong pemilihan buku bacaan dan minat baca siswa. Anak perempuan biasanya lebih suka membaca novel, cerita drama maupun cerita persahabatan, sedangkan anak laki-laki biasanya lebih suka cerita bertema kepahlawanan. 
Dengan demikian, minat membaca tidak dengan sendirinya dimiliki oleh seorang siswa melainkan harus dibentuk. Perlu suatu upaya, terutama dari kalangan pendidik, di samping dari lingkungan keluarganya sebagai lingkungan terdekat, untuk melatih, memupuk, membina, dan meningkatkan minat baca. Minat sangat memegang peranan penting dalam menentukan langkah yang akan kita kerjakan. Walaupun motivasinya sangat kuat tetapi jika minat tidak ada, tentu kita tidak akan melakukan sesuatu yang dimotivasikan pada kita. Begitu pula halnya kedudukan minat dalam membaca menduduki tingkat teratas, karena tanpa minat seseorang akan sukar melakukan kegiatan membaca.

Triatma (2016) faktor-faktor yang mempengaruhi minat baca meliputi faktor internal dan eksternal. Faktor internal mencakup perasaan, perhatian dan motivasi, sedangkan faktor eksternal meliputi peranan guru, lingkungan, keluarga dan fasilitas. Pembentukan kebiasaan membaca hendaklah dimulai sedini mungkin dalam kehidupan, yaitu sejak masa kanak-kanak. Pada masa kanak-kanak, usaha pembentukan minat yang baik dapat dimulai sejak kira-kira umur dua tahun, yaitu sesudah anak mulai dapat mempergunakan bahasa lisan (memahami yang dikatakan dan berbicara).

Untuk menumbuhkan sebuah minat baca dalam diri siwa tidak hanya sekedar motivasi biasa yang berikan orang tua tapi harus motivasi khusus yang utama dan diberikan fasilitas pendukung di rumah yang bisa memacu semangat siswa untuk membaca. Selain itu juga guru turut berperan aktif dalam mendorong timbulnya minat baca siswa dengan memberikan fasilitas membaca yang memadai di sekolah dan bimbingan belajar yang baik. Di SD
Inpres 26 Kabupaten Sorong khususnya kelas III sudah tersedia perpustakaan mini atau lebih dikenal pojok baca yang dapat memacu semangat siswa dalam membaca terutama saat istrihat atau saat tidak ada guru dikelas. Selain dapat memacu minat membaca siswa pojok baca juga sebagai alternatif hiburan siswa di kelas karena menyajikan buku bacaan yang menarik. Minat baca yang sudah mulai terbangun harus terus didorong oleh orang tua dengan memotivasi anak mereka untuk rajin membaca.

\section{METODE PENELITIAN}

Penelitian ini merupakan penelitian kuantitatif dengan mengunakan metode survey yang menuntut penjabaran variabel-variabel penelitian ke dalam indikator-indikator yang dapat diukur secara kuantitatif sehingga dapat digunakan model uji hipotesis. Dalam bukunya, Husein (2011:131) menjelaskan bahwa survey adalah suatu survey yang digunakan untuk menjelaskan hubungan kausal antara 2 variabel melalui pengujian hipotesis, survey dilakukan dengan cara mengambil sampel dari suatu populasi dengan menggunakan kuesioner sebagai alat pengumpul data. Dalam penelitian ini terdiri dari dua variabel yaitu variabel terikat yang disimbolkan dengan (y) dan variabel bebas yang disimbolkan dengan (x). Variabel bebas yakni motivasi orang tua sedangakn variabel terikat yakni minat membaca.

Populasi adalah keseluruhan subjek penelitian. Populasi yang diambil dalam penelitian ini adalah seluruh siswa kelas III SD Inpres 26 Kababupaten Sorong Tahun Ajaran 2016/2017, yang berjumlah 31 siswa dalam satu kelas. Sampel dalam penelitian ini diambil dengan teknik random sampling, artinya pengambilan sampel sebanyak satu kelas yaitu kelas III dengan jumlah 20 orang siswa. Pengambilan sampel sebanyak 20 siswa sudah memperhatikan rasio gender dimana sampel 
terdiri dari 10 siwa laki-laki dan 10 siswa perempuan serta sudah disesuaikan dengan jumlah siswa di kelas. Instrumen penelitian ini menggunakan angket terdiri atas angket motivasi orang tua dan minat membaca siswa. Angket merupakan teknik pengumpulan data yang dilakukan dengan cara memberi seperangkat pertanyaan atau pertanyaan tertulis kepada responden untuk dijawab, jenis kuesioner yang digunakan adalah kuesioner tertutup, dimana responden dapat memilih jawaban yang tersedia. Adapun alasan menggunakan kuesioner tertutup ini adalah untuk memberikan kemudahan kepada responden dalam memberikan jawaban dan untuk menghemat waktu penelitian. Selain itu juga untuk memudahkan pengolahan data yang diberikan responden. Sebelum angket digunakan terlebih dahulu dilakukan uji reliabilitas dan validitas instrument oleh validasi ahli. Analisis data menggunakan uji regresi linear sederhana. Kaidah pengujian signifikansi jika Fhitung > Ftabel, maka tolak Ho artinya signifikan dan Fhitung < Ftabel, maka terima Ho artinya tidak signifikan dengan taraf signifikan: $\alpha=$ 0,05. Dengan hipotesis penelitian "terdapat pengaruh antara motivasi orang tua terhadap minat baca siswa kelas III SD Inpres 26 Kabupaten Sorong”.

\section{HASIL DAN PEMBAHASAN}

Hasil penelitian dilakukan di SD Inpres 26 Kabupaten Sorong telah dilakukan uji analisis berdasarkan data yang ditemukan dilapangan menunjukan perolehan data yang dilanjutkan dilakukan persentase motivasi orang tua terhadap anak

Hasil penelitian deskripsi persentase untuk variable motivasi orang tua diperoleh skor total 1589 dengan rata-rata sebesar 3,575. Persentase sebesar 5\% menunjukan motivasi sangat baik dari orang tua, dan
75\% menunjukan kategori baik serta $20 \%$ menunjukan kategori cukup baik. Presentasi skor kategori motivasi orang tua dapat dilihat pada tabel 1 . berikut.

Tabel 1. Persentase Skor Kategori Motivasi Orang Tua

\begin{tabular}{lllll}
\hline No & Rentang & Kategori & $\begin{array}{l}\text { Jumlah } \\
\text { siswa }\end{array}$ & Presentase \\
\hline 1 & $\begin{array}{l}4,50- \\
5,00\end{array}$ & Sangat & 1 & $5,00 \%$ \\
2 & $3,50-$ & Baik & & \\
& 4,49 & Baik & 15 & $75,00 \%$ \\
3 & $2,50-$ & Cukup & 4 & $20,00 \%$ \\
& 3,49 & Baik & & \\
4 & $1,50-$ & Kurang & 0 & $0.00 \%$ \\
& 2,49 & Baik & & \\
5 & $1,00-$ & Tidak Baik & 0 & $0.00 \%$ \\
& 1,49 & . & \\
\hline
\end{tabular}

(Sumber: Data Penelitian)

Dari data tabel di atas dapat dilihat persentase skor kategori motivasi orang tua yang menunjukan bahwa mayoritas siswa sudah mendapatkan motivasi yang baik dari orang tua untuk menunjang hasil belajar yang baik. Lebih jelasnya dapat dilihat pada gambar 1.

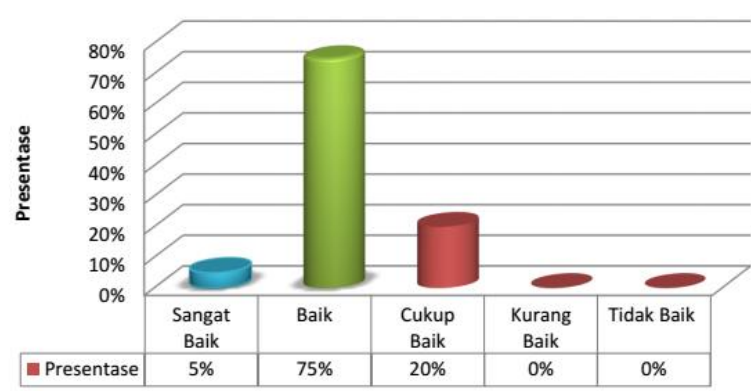

Gambar 1, Grafik persentase skor kategori motivasi orang tua

Untuk mengetahui seberapa besar minat baca siswa maka digunakan angket minat baca. Angket tersebut terdiri dari 24 pernyataan yang terdiri dari pernyataan 12 pernyataan positif dan 12 pernyataan negatif. Untuk mengukur minat baca maka digunakan skala likert dengan skor skala 1-5.

Berdasarkan hasil penelitian deskripsi persentase untuk variabel minat baca siswa setelah dilakukan uji analisis menunjukkan perolehan skor total 1788 dengan rata-rata skor 3,72. Persentase dengan kategori baik sebesar 
$85 \%$, dan presentasi kategori cukup baik sebesar $15 \%$. Presentasi skor kategori minat baca dapat dilihat pada tabel 2 berikut ini.

Tabel 2. Presentasi Skor Kategori Minat

\begin{tabular}{|c|c|c|c|c|c|c|}
\hline \multicolumn{7}{|c|}{ Baca } \\
\hline $\mathbf{N}$ & Rentan & Katego & Jumla & \multicolumn{3}{|c|}{ Presentase } \\
\hline 1 & $\begin{array}{l}4,50- \\
5,00\end{array}$ & $\begin{array}{l}\text { Sangat } \\
\text { Baik }\end{array}$ & 0 & \multicolumn{3}{|c|}{$0,00 \%$} \\
\hline 2 & $\begin{array}{l}3,50- \\
4,49\end{array}$ & Baik & & $\begin{array}{l}1 \\
7\end{array}$ & 85 , & $00 \%$ \\
\hline 3 & $\begin{array}{l}2,50- \\
3,49\end{array}$ & \multicolumn{2}{|c|}{ Cukup Baik } & & 3 & $\begin{array}{l}15,00 \\
\%\end{array}$ \\
\hline 4 & $\begin{array}{l}1,50- \\
2,49\end{array}$ & \multicolumn{2}{|c|}{ Kurang Baik } & & 0 & $0.00 \%$ \\
\hline 5 & $\begin{array}{l}1,00- \\
1,49\end{array}$ & \multicolumn{2}{|c|}{ Tidak Baik } & & 0 & $0.00 \%$ \\
\hline
\end{tabular}

Dari data tabel di atas dapat disajikan dalam Gambar 2. grafik persentase skor kategori motivasi orang tua sebagai berikut.

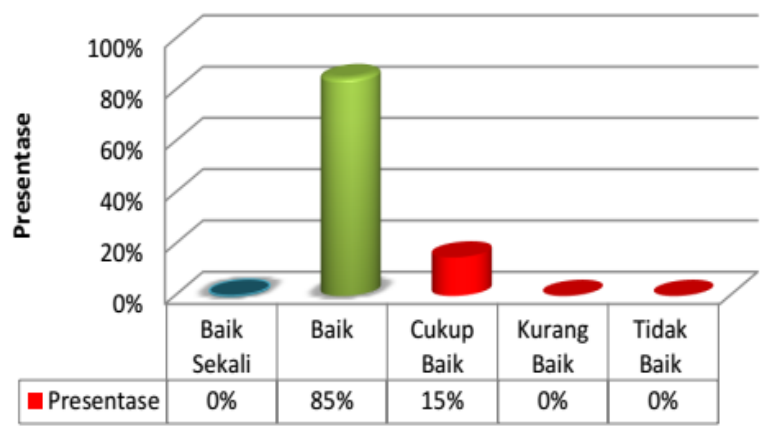

Gambar 2. Grafik Persentase Skor Kategori Motivasi Orang Tua

Berdasarkan tabel dan grafik di atas terlihat bahwa $85 \%$ minat baca dalam kategori baik dan $15 \%$ menunjukkan cukup baik. Hal tersebut menunjukkan bahwa minat baca siswa dalam sudah sangat tinggi dan cenderung mengalami peningkatan.

Hasil uji Analisis pengaruh motivasi orang tua terhadap minat baca dapat dilihat dari hasil uji regresi linier sederhana yang telah dengan mengjui data hasil penelitian dilakukan disajikan dalam tabel 3. di bawah ini.
Tabel 3. Hasil Uji Regresi Linier Sederhana

\begin{tabular}{ccccl}
\hline $\begin{array}{c}\text { Koefisien } \\
\text { Penduga } \\
\text { (a) }\end{array}$ & $\begin{array}{c}\text { Koefisien } \\
\text { Intersep } \\
\text { (b) }\end{array}$ & $\begin{array}{c}\text { Koefisien } \\
\text { Korelasi } \\
\text { (r) }\end{array}$ & $\begin{array}{c}\text { Koefisien } \\
\text { Determinasi } \\
\text { (D) }\end{array}$ & Ket. \\
\hline 71,96 & 0,219 & 0,206 & 0,042 & $\begin{array}{l}\text { Nilai } \\
\text { rhitung }>\text { rt }\end{array}$ \\
& & & & abel, \\
& & & & terdapat \\
& & & & pengaruh \\
& & & & yang \\
& & & & signifikan \\
& & & & \\
& & & &
\end{tabular}

(Sumber: hasil penelitian)

Untuk memperjelas hasil analisis

regresi sederhana antara motivasi orang tua terhadap minat baca siswa disajikan dalam bentuk gambar 3. berikut.

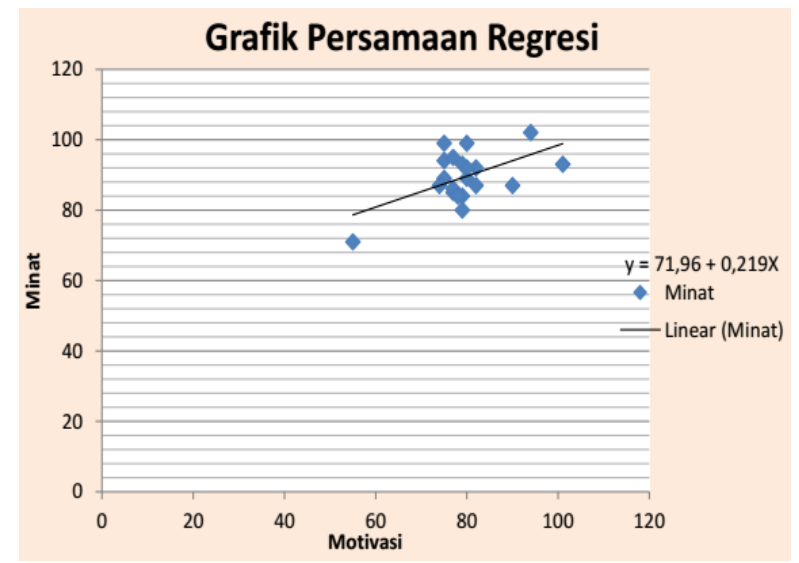

Gambar. 3 Grafik Persamaan Regresi

Berdasarkan perhitungan analisis secara cermat, maka didapat hasil interpretasi data sebagai berikut: 1) Interpretasi Persamaan Regresi, dari hasil perhitungan diperoleh nilai koefisien penduga intersap (a) sebesar 71,96 dan nilai koefisien intersap persamaan regresi (b) sebesar 0,219 sehingga dapat diperoleh regresi sederhananya adalah $\tilde{Y}=71,96+0,219 X$. Dari persamaan regresi dapat diketahui bahwa jika tidak ada perlakuan apa pun yang diberikan kepada anak, minat membaca anak adalah 00000. Jika ada perlakuan kepada anak meningkat 1,00 poin, maka minat membaca siswa akan meningkat sebesar 4,2\%. 2). Koofisien Korelasi (r), dari perhitungan menggunakan Microsoft excel office koefisien korelasi didapatkan nilai $\mathrm{r}$ sebesar 0,206. Dapat disimpulkan bahwa terdapat korelasi antara 
motivasi orang tua terhadap minat baca siswa. 3). Koefisien Determinasi (D), nilai koefisien determinasi dalam penelitian ini adalah $\mathrm{r} 2=$ 0,042. Koefisien determinasi menunjukkan bahwa sebesar $\mathrm{D}=4,2 \%$ minat baca siswa dipengaruhi oleh model motivasi orang tua. 4). Uji Signifikansi, dari perhitungan $F_{\text {tabel}}$, maka dapat diperoleh bahwa $F_{\text {tabel }}$ sebesar 1,729 pada taraf $0,01 \%$. H0 ditolak apabila $F_{\text {hitung }}>F_{\text {tabel }}$. Karena Fhitung $=19$ dan lebih besar dari Ftabel maka H0 ditolak. Untuk lebih jelasnya hasil analisis data dapat dilihat pada ringkasan analisis sebagai berikut.

Tabel 4. Hajil Uji Anova

\begin{tabular}{|c|c|c|c|c|c|c|}
\hline \multicolumn{2}{|c|}{ Model } & $\begin{array}{l}\text { Sum of } \\
\text { Squares }\end{array}$ & df & Mean Square & $\mathrm{F}$ & Sig. \\
\hline 1 & Regression & 290,781 & 1 & 290,781 & 7,720 &, $012^{\mathrm{a}}$ \\
\hline & Residual & 678,019 & 18 & 37,668 & & \\
\hline & Total & 968,800 & 19 & & & \\
\hline
\end{tabular}

Dari hasil penelitian yang dilakukan dengan menggunakan angket motivasi orang tua dan angket minat baca pada siswa kelas III SD Inpres 2 Kabupaten Sorong. Dilakukan beberapa uji untuk mendapatkan data hasil yang diinginkan uji yang dilakukan yaitu: Uji validitas dan Uji Realibilitas, uji ini dilakukan untuk mengetahui valid dan reliabel angket yang digunakan agar hasil yang didapat dari uji keduanya dinyatakan valid dan reliabel.

Penelitian ini menunjukan bahwa motivasi orang tua berperan penting dalam membangun minat baca siswa karena dorongan yang diberikan orang tua mampu memngembangkan minat membaca pada siswa. Hal itu dibuktikan dari hasi penelitian yaitu 5\% siswa sudah mendapatkan motivasi sangat baik dan sekitar $80 \%$ siswa SD Inpres 26 Kabupaten
Sorong sudah mendapakan motivasi yang baik dari orang tua sehingga memacu semangat untuk terus membaca. Dari total sempel yang diambil dapat dilihat bahwa jumlah skor motivasi orang tua 71,5. Angka tersebut menunjukan kualitas motivasi orang tua cukup tinggi atau baik, sedangkan untuk minat baca memperoleh total skor 74,4 dengan kategori tinggi atau baik. Dapat dilihat bahwa motivasi orang tua mempunyai pengaruh terhadap minat baca siswa kelas III SD Inpres 26. Kabupaten Sorong. Hal tersebut bisa meningkat apabila orang tua mampu memberikan motivasi secara baik dan terus menerus kepada siswa. Dari perhitungan koefisien korelasi didapat hasil $r$ sebesar 0,206 angka ini cenderung mendekati 1. Berdasarkan kriteria yang telah dijelaskan sebelumnya, dapat disimpulkan bahwa motivasi orangtua dan minat baca siswa memiliki korelasi yang tinggi. Nilai koefisien determinasi dalam penelitian ini adalah $\mathrm{D}=$ 0,042 koefisien determinasi menunjukkan 4,2\% minat baca siswa dipengaruhi oleh motivasi orang tua. Dari hasil perhitungan diperoleh nilai koefisien penduga intersap (a) sebesar 71,96 dan nilai koefisien intersap regresi (b) sebesar 0,219 sehingga persamaan regresi linier adalah $\tilde{Y}=71,96+0,219 X$. Nilai penduga intersap dan koefisien intersap didapat dari perpaduan skor motivasi orang tua dan skor minat baca siswa kelas III. Persamaan di atas menunjukkan adanya pengaruh motivasi orang tua terhadap minat baca siswa.

Dalam penelitian yang telah dilakukan, didapat harga Ftabel sebesar 1,729 pada taraf $1 \%$. Disini terlihat hasil $\mathrm{F}_{\text {hitung }}=19$ yang lebih besar daripada $F_{\text {tabel }}$ sehingga motivasi terhadap minat baca siswa kelas III SD Inpres 26 Kabupaten Sorong berada pada taraf sangat signifikan.

Menurut Sardiman (2016:85) mengemukakan tiga fungsi motivasi yaitu: 1) Mendorong timbulnya tingkah laku atau perbuatan. Tanpa motivasi tidak akan timbul 
suatu perbuatan. Motivasi dalam hal ini merupakan motor penggerak dari setiap kegiatan yang akan dikerjakan. 2) Motivasi berfungsi sebagai pengarah. Artinya motivasi mengarahkan perubahan untuk mencapai yang diinginkan. Dengan demikian, motivasi dapat memberikan arah dan kegiatan yang harus dikerjakan sesuai dengan rumusan tujuannya. 3) Motivasi berfungsi sebagai penggerak. Artinya mengerakkan tingkah laku seseorang. Selain itu, motivasi belajar berfungsi sebagai pendorong usaha dan pencapaian prestasi.

\section{KESIMPULAN}

Berdasarkan hasil penelitian dan pembahasan, maka dapat disimpulkan bahwa terdapat pengaruh motivasi orang tua terhadap minat baca siswa kelas III SD Inpres 26 Kabupaten Sorong yang ditunjukkan oleh $\mathrm{F}_{\text {hitung }}>\mathrm{F}_{\text {tabel }} .(19>$ 1,729). Besarnya pengaruh motivasi orang tua dapat dilihat dari nilai $\mathrm{R}$ square sebesar 4,2\%. Hal ini menunjukkan bahwa motivasi orang tua memberikan kontribusi positif terhadap peningkatan minat baca siswa dengan rata-rata mencapai 74,4.

\section{DAFTAR RUJUKAN}

Elmslie (2010). West Papuan Demographic Transition And The 2010 Indonesian Cencus: Slow Motion Genocide Or Not? Center for Peace and Conflict Studies, Sydney University.

Fathurrohman, Muhammad \& Sulistyorini.(2012). Belajar dan Pembelajaran. Yogyakarta : Teras.

Fitriana Nur. (2012). Hubungan Antara Minat Baca dengan Kemampuan Memahami Bacaan Siswa Kelas V SD Se-Gugus II Kecamatan Gedongtengen Kota Yogyakarta Tahun Ajaran 2011/2012. Yogyakarta: Universitas Negeri Yogyakarta.
Harjdasujana, A. (dkk.). (2010). Materi Pokok Membaca. Jakarta: Universitas. Terbuka.

Husein, Umar. (2011). Metode Penelitian untuk Skripsi dan Tesis Edisi 11. Jakarta: PT. Raja Gravindo Persada.

Mursalim, M., Jusmin, J., \& Wulandari, N. (2020). Pola Asuh Orang Tua Terhadap Kemampuan Bersosialisasi Pada Siswa Kelas IV DI SD INPRES 102 MALANU Kota Sorong. Jurnal Papeda (Publikasi Pendidikan Dasar), 2(1), 1-9.

Rahim, Farida. (2012). Pengajaran Membaca di Sekolah Dasar. Jakarta : PT. Bumi Aksara.

Ratnasari, Yunita. (2011). Pengaruh Pergaulan Teman Sebaya Terhadap Minat Baca Siswa Kelas V SD Negeri Bojongsari 1 Kabupaten Purbalingga. Skripsi Sarjana pada FIP UNY Yogyakarta.

Rohani, Ahmad. \& Ahmadi, Abu. (2010). Pengelolaan Pengajaran. Jakarta: Rineka Cipta.

Salim, Peter. (2012). Kamus Besar Bahasa Indonesia. Jakarta : Balai Pustaka.

Sardiman A.M. (2016). Interaksi dan Motivasi Belajar Mengajar. Jakarta: PT Raja Grafindo Persada.

Slameto. (2010). Belajar dan Faktor - Faktor Yang Mempengaruhi. Jakarta: Rineka Cipta.

Somadoyo, Samsu. (2011). Strategi dan Tekhnik Pembelajaran Membaca. Yogyakarta : Graha Ilmu.

Sutrisno, Edy. (2011). Manajemen Sumber Daya Manusia. Jakarta: Kencana Prenada Media Group.

Triatma, IN. (2016). Minat Baca Pada Siswa Kelas VI Sekolah Dasar Negeri Delegan 2 Prambanan Sleman Yogyakarta. Jurnal Teknologi Pendidikan. Vol. 5, No. 6, Pg. 166-178.

Zuchdi, Darmiyati. (2012). Strategi Meningkatkan Kemampuan Membaca(Peningkatan Komprehensi). Yogyakarta: UNY Pres. 